\title{
Australian Journal of Crop Science \\ Pollen diversity of the tidal swamp rice (Oryza sativa L.) cultivars collected from South Kalimantan, Indonesia
}

\author{
Dindin H. Mursyidin ${ }^{1,2}$, Issirep Sumardi ${ }^{2}$, Purnomo ${ }^{2}$ and Budi S. Daryono ${ }^{2 *}$ \\ ${ }^{1}$ Faculty of Mathematics and Natural Sciences, Universitas Lambung Mangkurat, South Kalimantan, 70714, \\ Indonesia \\ ${ }^{2}$ Faculty of Biology, Universitas Gadjah Mada, Yogyakarta, 55281, Indonesia
}

*Corresponding author: bs_daryono@mail.ugm.ac.id

\begin{abstract}
The characteristics of pollen morphology is an important key to determine the germplasm. In this study, we investigated the pollen morphology of the tidal swamp rice (Oryza sativa L.) cultivars using scanning electron microscopy (SEM). The phenetic relationship of this germplasm was also reconstructed based on UPGMA method. Nine cultivars of the tidal swamp rice, comprise eight from the South Kalimantan Province, Indonesia, and one from Sumatera Island (a comparison), were used in this study. The SEM analysis revealed the distinct variations among pollen rice morphology, particularly in the pattern of exine surface ornamentation. Two form of the ornamentation discovered for this germplasm, namely insular and mixed-granular type. According to the UPGMA analysis, the tidal swamp rice cultivars clustered into four groups, where Pandak Putih and Lakatan Pacar have the farthest relationship, and Pandak Putih and Lakatan Wangi were the closest. These findings might be useful in the future rice breeding program, particularly in the development of new rice cultivars for the tidal swamp areas.
\end{abstract}

Keywords: Rice; genetic diversity; phenetic relationship; pollen; plant structure.

Abbreviations: SEM_scanning electron microscopy; UPGMA_unweighted pair group method with arithmetic mean.

\section{Introduction}

An increasing number of the world's population and a gradual decline of agricultural lands are two serious problems that cause food insecurity (Duan et al., 2013). Thus, many countries with a higher population are trying to resolve these problems by increasing crop productivity and the development of new breeding cultivars (Anumalla et al., 2015; Ford-Lloyd et al., 2011). Since rice consumed by the most of the world's population (Muthayya et al., 2014), breeding practices is directed to the discovery of specific germplasm and the development of new rice cultivars with high productivity (Duan et al., 2013).

The tidal swamp rice (Oryza sativa L.) is an essential germplasm for development new rice cultivars (Tandekar and Koshta, 2014). As part of indigenous germplasm, this being reserves many useful genes, particularly for stress tolerance, high yielding stability, and adaptability to the marginal condition (Sanghera et al., 2013). Thus, this germplasm can be explored both to broaden the narrow genetic diversity and increased the number of existing cultivars with important traits (Anumalla et al., 2015). However, most of this germplasm is not utilized (incorporated) optimally in a modern rice breeding program. Hundreds of the tidal swamp rice cultivars found in the ricefarming regions of the Indonesian archipelago, but many of these are not well characterized (Khairullah et al., 1998). In general, characterization of rice germplasm is undertaken based on the morphological marker, particularly on macro- structural levels (Datta and Chaturvedi, 2004). However, this marker has several disadvantages, including time-consuming and unreliable to distinguish species with close related taxes, like rice (Liu et al., 2012). This marker has some drawbacks as well, such as low polymorphism, low heritability, late expression, and vulnerable to environmental influences (Anumalla et al., 2015). Thus, applying other methods with more accurate is an important task to characterize this germplasm.

Ultrastructure analysis using SEM method is an alternative marker to characterize rice germplasm today (Sinha et al., 2015). This marker can be useful to complement macrostructural analysis (Datta and Chaturvedi, 2004). Since pollen characters widely accepted as reliable taxonomic characters, some studies are applying this marker to offer information on the rice pollen morphology, both cultivated and wild rice (Chaturvedi et al., 1998). Datta and Chaturvedi (2004) are successful in characterizing Basmati rice based on pollen exine surface ornamentation. Mander et al., (2013) are also successful in quantifying the size and density of sculptural elements of the exine surface ornamentation of Poaceae pollen.

The pollen morphology, particularly in the exine surface ornamentation, is less affected by environmental factors (Delph et al., 1997). A few studies have demonstrated that some environmental factors, such as temperature and drying conditions, does not affect this structure, but only 
change the size and chemical composition (Delph et al., 1997; Ejsmond et al., 2015). Schneider et al., (2009) reported another factor which can influence the pollen morphology (size), such as cytology (ploidy level), ecology, floral morphology or physiological constraints.

This study focused on investigating the pollen characteristics, particularly from the tidal swamp rice of the South Kalimantan Province, Indonesia, by SEM method. This study also directed to reconstructing the phenetic relationship of that germplasm by the UPGMA method. The information on this character is important in the rice breeding program, but that information is limited and has not been widely available. In other side, the South Kalimantan Province is an important rice-growing area in our country because many of this germplasm has unexplored (Khairullah et al., 1998). Thus, the results of this study may be useful to support the rice breeding program in the future.

\section{Results and Discussion}

\section{The pollen morphology of the tidal swamp rice}

The tidal swamp rice cultivars of the South Kalimantan Province shows unique pollen morphology, particularly on the basis of pollen shape (figure 2), size (table 2) and exine surface ornamentation (figure 3 ). According to table 2 , this germplasm has the pollen diameter, ranging between 57.20 to $75.98 \mu \mathrm{m}$, the germ-pore between $1.98-5.26 \mu \mathrm{m}$, and annulus $8.60-11.97 \mu \mathrm{m}$. In this case, Sardani has the largest pollen diameter $(75.98 \mu \mathrm{m})$, while Pandak Putih is the smallest $(57.20 \mu \mathrm{m})$. Compared to another cultivar, Ganal Perak has the largest germ-pore diameter $(5.26 \mu \mathrm{m})$, while Pandak Putih is the smallest $(1.98 \mu \mathrm{m})$.

According to figure 2, all pollen of each cultivar represented a round-spherical (oblate-spheroidal) form. In general, this material equipped with a single germ-pore and annulus, classified as a monoporate-annulate type (figure 2 ). This pollen type, however, is usually found in the Poaceae (Erdtman, 1952); Kellogg, 2015). Several researchers have found a similar type of such pollen. For example, Perveen (2006) have reported a monoporate-annulate type in 14 plants, belongs to the genera of Poaceae. Liu et al., (2005) and Nazir et al., (2013) also reported such pollen on Eustachys and Avenae tribes, respectively. Similarly, Sánchez et al., (2006) are finding a similar type of such pollen in the wild rice $O$. grandiglumis.

Although the tidal swamp rice pollen is remarkably uniform, this material shows unique characteristic, particularly in the pattern of exine surface ornamentation (figure 3). According to table 2, this germplasm has both an insular and mixed-granular pollen types. In this case, the cultivars of Siam Gadis, Ganal Perak, Pandak Putih, Lakatan Wangi, and Ciherang, as well as Sardani, have an insular pollen type. Whereas, a mix-granular type possessed by pollen cultivars of Karang Dukuh, Lakatan Pacar, and Banih Kuning. These results are concordant with the finding of Chaturvedi et al., (1998) when characterizing 19 genera of Oryza, including cultivated rice (Indica, Japonica, and Javanica sub-species).

According to Chaturvedi et al., (1998), the pattern of exine surface ornamentation classified into three basic forms, namely granular, spinular, and insular type. A granular type, characterized by the presence of granular protrusions on the surface of the pollen wall, commonly found in Javanica (Chaturvedi et al., 1998). An insular type, characterized by widely spaced granules or spinules in the pollen exine surface, found in both Japonica and Indica rice. Datta and Chaturvedi (2004) described more detail information on an insular type of Basmati rice.

In general, the pollen morphology, as mention above, is less affected by environmental factors (Delph et al., 1997). While a few studies have demonstrated that some environmental factors, such as temperature and dry condition, can affect this material, its morphology does not change, either in size or chemical composition only (Ejsmond et al., 2015). However, these factors do not affect the pollen morphology (shape), but only either in size or chemical composition, particularly during flowering development (Ejsmond et al., 2011; Delph et al., 1997). Schneider et al., (2009) reported some other factors which can influence the pollen grain size, such as cytology (ploidy level), ecology, floral morphology or physiological constraints. Thus, the pollen morphology is one of an important key to determine the germplasm.

\section{The phenetic relationship of the tidal swamp rice}

The phenetic relationship is one important parameter in supporting breeding strategies, particularly in the development of new superior cultivars. In this study, the tidal swamp rice exhibited unique relationship based on the pollen morphology (figure 4). The UPGMA analysis shows that this germplasm clustered into two main groups, and divided into four groups at the similarity coefficient of 0.80 .

According to the figure 4, the Pandak Putih and Lakatan Wangi cultivars have a very close relationship, with a similarity coefficient of 0.96 , while Pandak Putih and Lakatan Pacar are the farthest. In plant breeding, individuals with a distant genetic relationship can be used as a parent in the developing new rice cultivar, since hybridization between them can produce offspring with high genetic variability (Anumalla et al., 2015). Hence, the latest cultivars have an opportunity as parent candidates in the future rice breeding program, specifically for the tidal swamp areas.

Based on figure 4 as well, it is known that Sardani (a comparison cultivar) and Siam Gadis included in the same group and they have a relatively close relationship, where both are having geographical differences. According to Yawen et al., (2003), the differences of the geographic region usually, but not necessarily, may affect the phenotype differences in germplasm. As in genetics concept, the phenotype is an interaction result between genotype and its environmental factors (Frankham et al., 2002).

While this marker may not have the capability to distinguish the rice germplasm geographically, it has a good chance to apply in other rice germplasm. It is because hundreds or even thousands of the indigenous rice germplasm in Indonesia are still stored and not well understood (Khairullah et al., 1998). Thus, combine application between pollen morphology and another marker, particularly molecular markers, are important to be applied. In this context, the molecular markers not only reveals the phylogenetic relationship of germplasm but also address the evolutionary potential for the future breeding program (Frankham et al., 2002). 
Table 1. A list of the tidal swamp rice cultivars used in this study.

\begin{tabular}{|c|c|c|c|c|c|}
\hline Cultivar name & Code & Genetic status & Subspecies & Endosperm type & Origin (District/Regency/Province) \\
\hline Siam Gadis & $A$ & Landrace & Javanica & Non-glutinous & Kurau, Tanah Laut, South Kalimantan \\
\hline Karang Dukuh & B & Landrace & Indica & Non-glutinous & Anjir Muara, Barito Kuala, South Kalimantan \\
\hline Ciherang & C & Improved & Javanica & Non-glutinous & Aluh Aluh, Banjar, South Kalimantan \\
\hline Lakatan Pacar & D & Landrace & Javanica & Glutinous & Gambut, Banjar, South Kalimantan \\
\hline Banih Kuning & $\mathrm{E}$ & Landrace & Javanica & Non-glutinous & Aluh Aluh, Banjar, South Kalimantan \\
\hline Ganal Perak & $\mathrm{F}$ & Landrace & Javanica & Non-glutinous & Aluh Aluh, Banjar, South Kalimantan \\
\hline Sardani $^{*}$ & G & Landrace & Indica & Non-glutinous & Sumatera Island \\
\hline Pandak Putih & $\mathrm{H}$ & Landrace & Javanica & Non-glutinous & Aluh Aluh, Banjar, South Kalimantan \\
\hline Lakatan Wangi & I & Landrace & Javanica & Glutinous & Aluh Aluh, Banjar, South Kalimantan \\
\hline
\end{tabular}

Table 2. Characteristics of pollen morphology of the tidal swamp rice cultivars.

\begin{tabular}{|c|c|c|c|c|c|c|c|c|}
\hline Cultivar name & Pollen type & $\begin{array}{c}\text { Pollen diameter } \\
(\mu \mathrm{m})\end{array}$ & $\begin{array}{l}\text { Pollen size shortest } \\
\text { x longest axis }\end{array}$ & $\begin{array}{l}\text { Ratio of pollen } \\
\text { size }\end{array}$ & $\begin{array}{c}\text { Pore diameter } \\
(\mu \mathrm{m})\end{array}$ & $\begin{array}{c}\text { Annulus } \\
\text { diameter }(\mu \mathrm{m})\end{array}$ & $\begin{array}{c}\text { Annulus } \\
\text { height }(\mu \mathrm{m})\end{array}$ & Exine ornamentation \\
\hline Siam Gadis & $\begin{array}{l}\text { monoporate, } \\
\text { annulate }\end{array}$ & $66.32 \pm 0.07$ & $32.51 \times 33.82$ & 0.96 & 3.72 & 9.19 & 1.65 & $\begin{array}{l}\text { Insular, insulae form a mozaic } \\
\text { pattern }\end{array}$ \\
\hline Karang Dukuh & $\begin{array}{l}\text { monoporate, } \\
\text { annulate }\end{array}$ & $65.18 \pm 0.01$ & $32.33 \times 32.85$ & 0.98 & 3.50 & 7.46 & 1.48 & Mixed granulose \\
\hline Ciherang & $\begin{array}{l}\text { monoporate, } \\
\text { annulate }\end{array}$ & $67.92 \pm 0.47$ & $33.26 \times 34.66$ & 0.96 & 2.38 & 7.74 & 1.48 & Insular, insulae ruguloid \\
\hline Lakatan Pacar & $\begin{array}{l}\text { monoporate, } \\
\text { annulate }\end{array}$ & $70.34 \pm 0.30$ & $34.50 \times 35.84$ & 0.96 & 4.65 & 10.64 & 2.13 & Mixed granulose \\
\hline Banih Kuning & $\begin{array}{l}\text { monoporate, } \\
\text { annulate }\end{array}$ & $75.85 \pm 0.26$ & $37.64 \times 38.21$ & 0.99 & 4.98 & 11.97 & 2.15 & Mixed granulose \\
\hline Ganal Perak & $\begin{array}{l}\text { monoporate, } \\
\text { annulate }\end{array}$ & $70.34 \pm 0.01$ & $33.78 \times 36.56$ & 0.92 & 5.26 & 11.09 & 1.96 & $\begin{array}{l}\text { Insular, insulae form a mozaic } \\
\text { pattern }\end{array}$ \\
\hline Sardani ${ }^{*}$ & $\begin{array}{l}\text { monoporate, } \\
\text { annulate }\end{array}$ & $75.98 \pm 0.63$ & $36.95 \times 39.04$ & 0.95 & 4.06 & 9.90 & 2.30 & $\begin{array}{l}\text { Insular, insulae form a mozaic } \\
\text { pattern }\end{array}$ \\
\hline Pandak Putih & $\begin{array}{l}\text { monoporate, } \\
\text { annulate }\end{array}$ & $57.20 \pm 0.12$ & $27.38 \times 29.82$ & 0.92 & 1.98 & 8.60 & 1.17 & $\begin{array}{l}\text { Insular, insulae form a mozaic } \\
\text { pattern }\end{array}$ \\
\hline Lakatan Wangi & $\begin{array}{l}\text { monoporate, } \\
\text { annulate }\end{array}$ & $61.72 \pm 0.15$ & $30.35 \times 31.52$ & 0.96 & 2.78 & 9.10 & 1.38 & $\begin{array}{l}\text { Insular, insulae form a mozaic } \\
\text { pattern }\end{array}$ \\
\hline
\end{tabular}



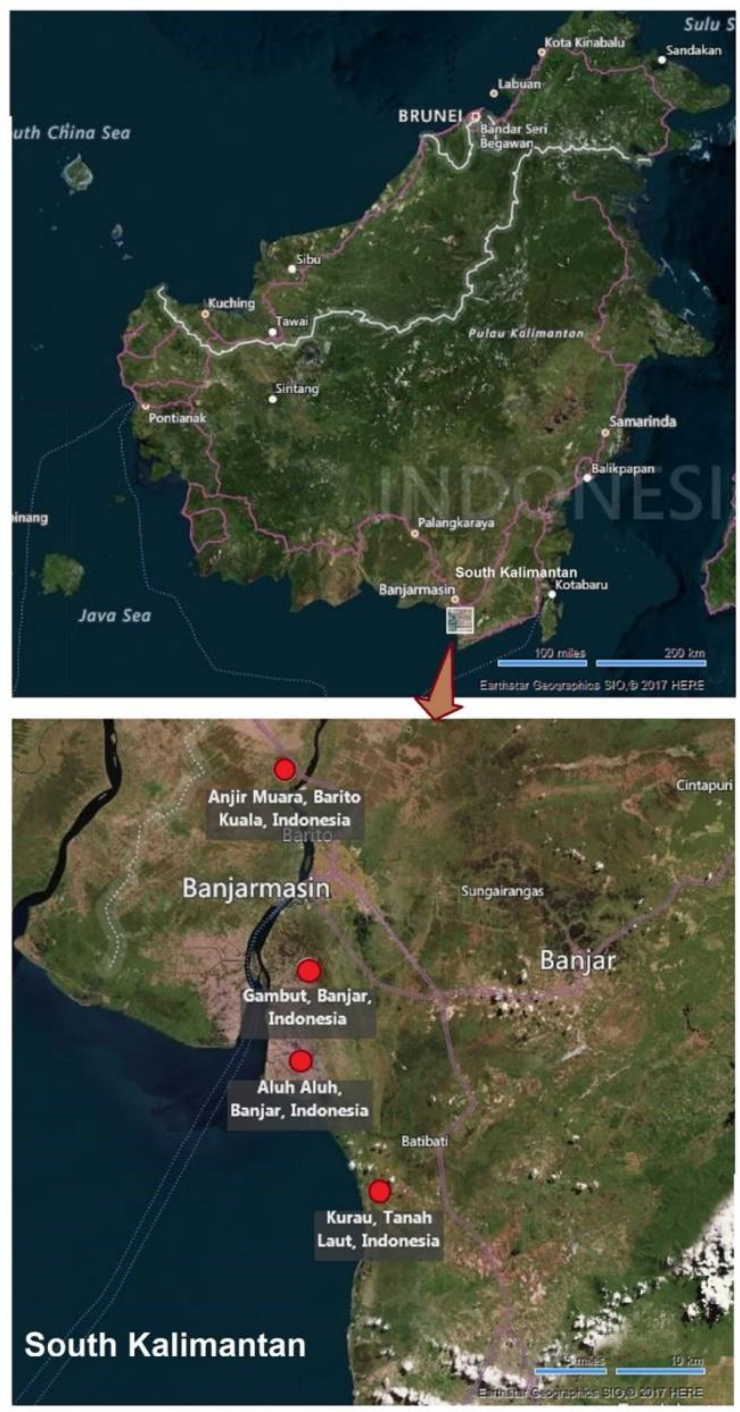

Fig 1. Map of Kalimantan Island showing the collecting sites of the tidal swamp rice cultivars in the South Kalimantan Province, Indonesia. Red point indicates four specific locations where the rice germplasm collected.

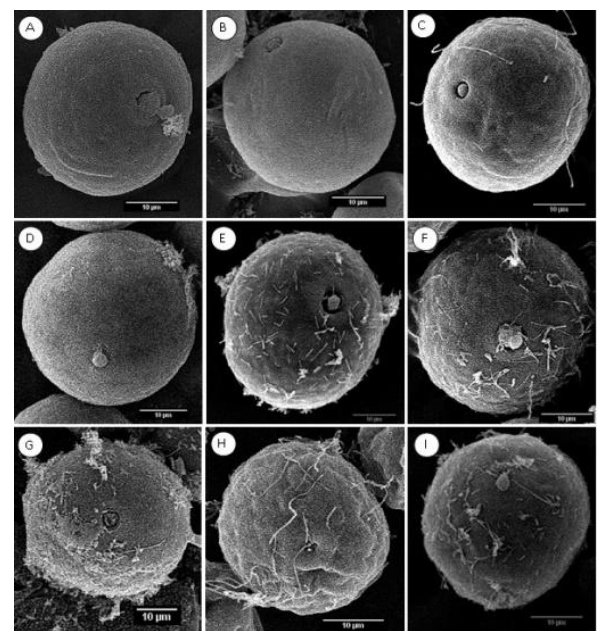

Fig 2. The pollen morphology of the tidal swamp rice cultivars, at a SEM magnification of $\times 2,000$, all indicate a round-spherical form. The names of each cultivar listed in table 1. 


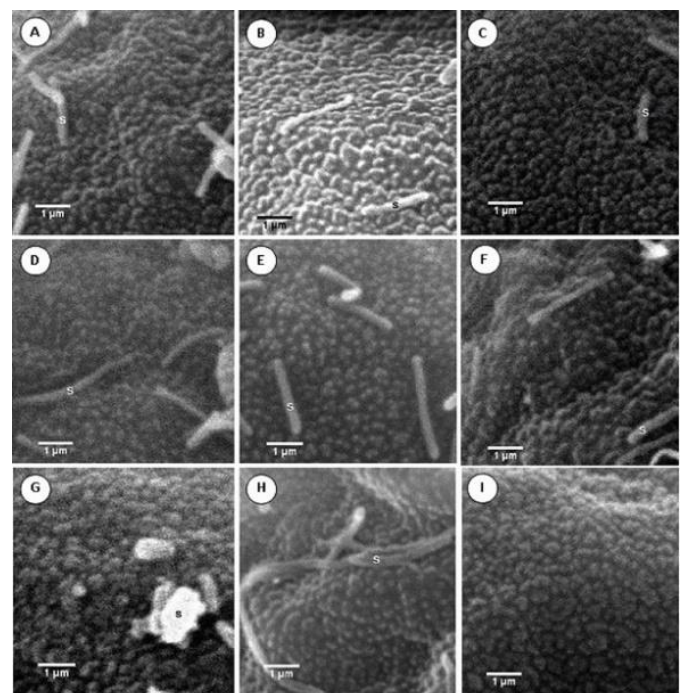

Fig 3. The pollen exine surface ornamentation of the tidal swamp rice cultivars, at a SEM magnification of $x 10,000$, showing a form of insular (A, C, F-I) and mixed granulose (B, D, E) type. The names of each cultivar listed in table 1.

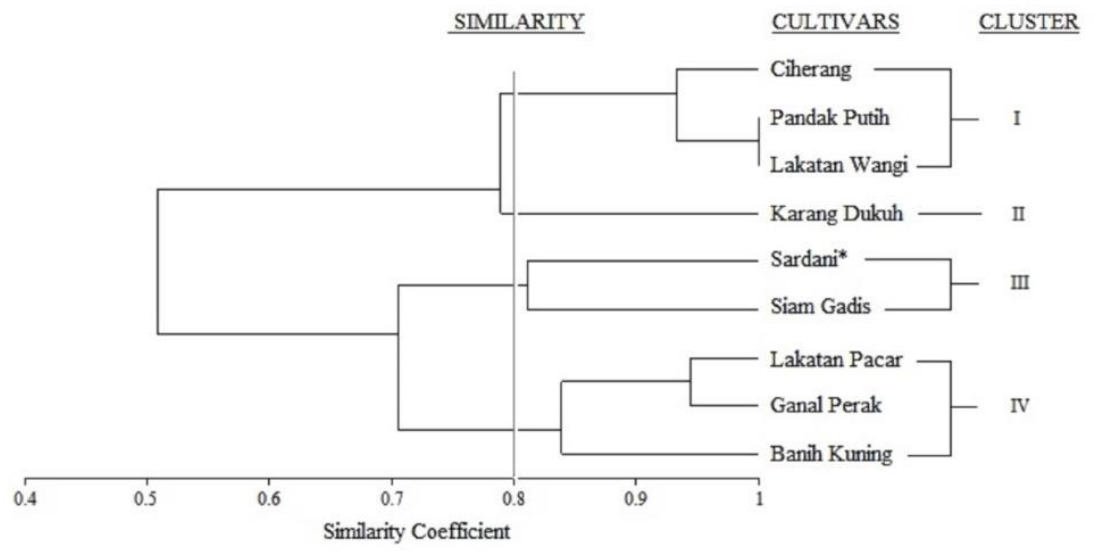

Fig 4. The phenetic relationship of the tidal swamps rice cultivars based on the pollen morphology (UPGMA analysis). The Sardani (marked), a comparison cultivar, clustered with Siam Gadis in a similar group.

\section{Materials and Methods}

\section{Plant materials and pollen samples}

We have used a total of nine cultivars of traditional rice germplasm, comprises eight of the tidal swamp areas of the South Kalimantan Province, Indonesia, and one of the tidal swamp areas of Sumatera Island, Indonesia (a comparison). The last cultivar mentioned was obtained from the Indonesian Swampland Agriculture Research Institute, South Kalimantan, Indonesia. The sampling locations where the tidal swamp rice collected can be seen in figure 1 . All of that germplasm listed in table 1 . The name of each cultivar was recognized, particularly on the basis of seed appearance (Mursyidin et al., 2017).

\section{Samples preparation}

The preparation of the pollen samples was conducted by following Sánchez et al., (2006) procedure. The preparation started by sample fixation, using $2.5 \%$ glutaraldehyde and
$2 \%$ paraformaldehyde solutions, both dissolved in $0.1 \mathrm{M}$ sodium phosphate buffer ( $\mathrm{pH}$ 7.4). The samples then washed with the sodium phosphate buffer and were fixed with $1 \%$ osmium tetraoxide in the $0.1 \mathrm{M}$ sodium phosphate buffer. After that, the preparation followed by samples washed with distilled water and dehydrated in an ethanol gradient. Once completed, samples then washed again with terbutaline alcohol as much as four times and dried using freeze-drying methods. At the final stage of preparation, the samples mounted on aluminum bases, covered with $20 \mathrm{~nm}$ of gold (using lonic Coater), and observed by scanning electron microscopes (JEOL JSM-5000, Japan) in an acceleration voltage of $20 \mathrm{kV}$.

\section{Data analysis}

The data analysis performed on some of the pollen morphological characters, including the diameter of the pollen grain, both polar and equatorial axis, germination pore and annulus diameter, also the pattern of exine surface ornamentation. SEM photomicrograph was taken uniformly 
for all the characters, at a magnification of $x 2,000$ to $x$ 10,000 . Characterization of pollen exine surface ornamentation referred to Datta and Chaturvedi (2004). Similarity analysis and phenetic reconstruction conducted by UPGMA method, using the software of MVSP version 3.1 (Kovach, 2003).

\section{Conclusion}

The tidal swamp rice cultivars of the South Kalimantan Province, Indonesia shows the unique characteristics of the pollen morphology, particularly in the pattern of exine surface ornamentation. Two forms of that ornamentation found in this study, namely an insular and mixed-granular type. The UPGMA analysis revealed that this germplasm clustered into four groups, where Pandak Putih and Lakatan Pacar have the farthest relationship, and Pandak Putih and Lakatan Wangi were the closest. These findings might be useful for breeders in the future rice breeding program, particularly in the development of new rice cultivars for the tidal swamp areas.

\section{Acknowledgement}

The authors wish to thank the Director of the Indonesian Swampland Agriculture Research Institute, South Kalimantan, Indonesia for providing Sardani rice as a comparison cultivar. We are grateful to Rubi, Rifa'i, and Zia for helping the rice collection.

\section{References}

Anumalla M, Roychowdhury R, Geda CK, Mazid M, Rathoure AK (2015) Utilization of plant genetic resources and diversity analysis tools for sustainable crop improvement with special emphasis on rice. Int J Adv Res. 3:1155-1175.

Chaturvedi M, Datta K, Nair PKK (1998) Pollen morphology of Oryza (Poaceae). Grana. 37:79-86.

Datta K, Chaturvedi M (2004) Pollen morphology of Basmati cultivars (Oryza sativa race Indica) - exine surface ultrastructure. Grana. 43:89-93.

Delph LF, Johannsson MH, Stephenson AG (1997) How environmental factors affect pollen performance: Ecological and evolutionary perspectives. Ecology. 78(6):1632-1639.

Duan M, Sun Z, Shu L, Tan Y, Yu D, Sun X, Liu R, Li Y, Gong S, Yuan D (2013) Genetic analysis of an elite super-hybrid rice parent using high-density SNP markers. Rice. 6:1-15.

Ejsmond MJ, Wrońska-Pilarek D, Ejsmond A, Dragosz-Kluska D, Karpińska-Kołaczek M, Kołaczek P, Kozłowski J (2011) Does climate affect pollen morphology? Optimal size and shape of pollen grains under various desiccation intensity. Ecosphere. 2(10):117.

Ejsmond MJ, Ejsmond A, Banasiak L, Karpińska-Kołaczek M, Kozłowski J, Kołaczek P (2015) Large pollen at high temperature - an adaptation to increased competition on the stigma? Plant Ecol. 216(10):1407-1417.

Erdtman G (1952) Pollen morphology and plant taxonomy: Angiosperms. Almquiste Wiksell, Stockholm.
Ford-Lloyd BV, Schmidt M, Armstrong SJ, Barazani O, Engels J, Hadas R, Hammer K, Kell SP, Kang D, Khoshbakht K, Li Y, Long C, Lu B-R, Ma K, Nguyen VT, Qiu L, Ge S, Wei W, Zhang Z, Maxted N (2011) Crop wild relativesundervalued, underutilized and under threat? BioScience. 61:559-565.

Frankham R, Ballou JD, Briscoe DA (2002) Introduction to Conservation Genetics. Cambridge University Press, Cambridge. 641.

Khairullah I, Imberan M, Subowo S (1998) Adaptability and acceptability of rice varieties on a tidal swamp area of South Kalimantan. Kalimantan Scientiae. 47: 38-50. (Indonesian)

Kellogg EA (2015) Flowering plants, monocots: The families and genera of vascular plants. Springer, Switzerland.

Kovach WL (2003) MVSP-Multi-variate statistical package, ver. $\quad 3.1^{\prime}$. Kovach Computing Service. (www.kovcomp.co.uk)

Liu P, Cai X-X, Lu B-R (2012) Single-seeded indel fingerprints in rice: an effective tool for indica-japonica rice classification and evolutionary studies. J Syst Evol. 50:111.

Liu Q, Zhao N, Hao G (2005) Pollen morphology of Eustachys tenera (Chloridoideae, Gramineae). Pak J Bot. 37:503-506.

Mander L, Li M, Mio W, Fowlkes CC, Punyasena SW (2013) Classification of grass pollen through the quantitative analysis of surface ornamentation and texture. Proc R Soc B. 280:1-7.

Mursyidin DH, Nazari YA, Daryono BS. 2017. Tidal swamp rice cultivars of South Kalimantan Province, Indonesia: A case study of diversity and local culture. Biodiversitas. 18(1): 427-432.

Muthayya S, Sugimoto JD, Montgomery S, Maberly GF (2014) An overview of global rice production, supply, trade, and consumption. Ann N Y Acad Sci. 1324:7-14.

Nazir A, Khan MA, Abbasi AM, Zahidullah (2013) Palynological studies in tribe Aveneae (Poaceae) from Potohar of Pakistan. Int J Sci Basic Appl Res. 10:120-125.

Perveen A (2006) A contribution to the pollen morphology of family Gramineae. World Appl Sci J. 1:60-65.

Sánchez E, Quesada T, Espinoza AM (2006) Ultrastructure of the wild rice Oryza grandiglumis (Gramineae) in Costa Rica. Int J Trop Biol. 54:377-385.

Sanghera GS, Kasyap SC, Parray GA (2013) Genetic variation for grain yield and related traits in temperate red rice (Oryza sativa L.) ecotypes. Not Sci Biol. 5:400-406.

Schneider JV, Klie D, Kacza J, Huertas ML (2009) Infrageneric variability of pollen morphology in Palaua (Malveae, Malvaceae) and the taxonomic utility of quantitative pollen characters. Grana. 48: 258-269.

Sinha AK, Mallick GK, Mishra PK (2015) Diversity of grain morphology on traditional rice varieties (Oryza sativa L.) of lateritic region of West Bengal. World J Agric Sci. 11:48-54.

Tandekar K, Koshta N (2014) To study the agromorphological variation and genetic variability in rice germplasm. Middle-East J Sci Res. 20:218-224.

Yawen Z, Shiquan S, Zichao L, Zhongyi Y, Xiangkun W, Hongliang Z, Guosong W (2003) Ecogeographic and genetic diversity based on morphological characters of indigenous rice (Oryza sativa L.) in Yunnan, China. Genet Res Crop Evol. 50:567-577. 